\title{
Kecerdasan Emosional Dan Kecemasan Mahasiswa Bimbingan Skripsi di Universitas Syiah Kuala
}

\author{
${ }^{1}$ Teuku Rijalul Fikry, ${ }^{2}$ Maya Khairani \\ Prodi Psikologi Universitas Syiah Kuala \\ Correspondence email: Rijalulfikry92@gmail.com
}

\begin{abstract}
Abstrak: Skripsi adalah tugas akhir yang harus diselesaikan oleh mahasiswa guna untuk mempeoleh gelajar sarjana.Skripsi dibuat oleh seorang mahasiswa di bawah bimbingan dosen pembimbing dengan melakukan bimbingan secara langsung. Proses bimbingan sering kali menimbulkan kecemasan pada diri mahasiswa. Kecemasan merupakan suatu reaksi emosi dari rasa takut dan cemas.Untuk mengendalikan dan mengontrol kecemasan trsebut dibutuhkan kemampuan untuk mengontrol dan mengendalikan emosi seperti kecerdasan emosional.Penelitian ini bertujuan untuk melihat hubungan kecerdasan emosional dengan kecemasan pada mahasiswa yang melakukan bimbingan skripsi di Unversitas Syiah Kuala.Penelitian dilakukan pada 257 mahasiswa yang dipilih berdasarkan teknik purposive sampling. Data penelitian dikumpulkan menggunakan skala adaptasi yaitu skala kecerdasan emosional Schutte Emotional Intelligence Scale (SEIS) yang disusun oleh Schutte, dkk (1998) dan skala kecemasan dari Depression Anxiety Stress Scale (DASS) yang telah diadaptasi oleh Damanik (2011). Data dianalisa menggunakan teknik spearman, dengan hasil nilai $p=0,000 \quad(p<0,05)$ dengan nilai koefisien korelasi $-0,139$. Hal ini menunjukkan bahwa terdapat hubungan negative antara kecerdasan emosional dengan kecemasan pada mahasiswa yang melakukan bimbingan skripsi di Universitas Syiah Kuala dengan kontribusi 4,3\% $(r$ squared $=0,043)$. Hal ini bermakna semakin tinggi kecerdasan emosional individu, maka semakin rendah kecemasan individu tersebut, serta sebaliknya.
\end{abstract}

Kata kunci: Kecerdasan Emosional, Kecemasan, Skripsi, Mahasiswa

\begin{abstract}
Undergraduate research is the final project in order to completed the undergraduate degree. It is made by a college's student under supervision. The direction process often cause anxiety for student. Anxiety is an emotional reaction of fear and anxious, thus requires the ability to control emotions such emotional intelligence. This study aimed to see the relationship of emotional intelligence and anxiety in Syiah Kuala University's student while getting direction of research. The study was conducted on 257 student that were selected by purposive sampling technique. The data was collected by Schutte Emotional Intelligent Scale (SEIS) from Schutte, et al (1998) and anxiey scale of Depresion Anxiety Stress Scale (DASS) that has been adapted by Damanik (2011). Data were analyzed by spearman technique with result $\mathrm{p}=0.000(\mathrm{p}=0.05)$ and correlation coefficient score -0.139. This show a negative relationship between emotional intelliegence and anxiety on Syiah Kuala University's student while getting direction of research with $4.3 \%$ contribution ( $r$-squared $=0.043$ ). It's mean individual with the high level of emotional intelligence followed by the low level of anxiety, and vice versa.
\end{abstract}

Keywords: Emotional Intelligence, Anxiety, Undergraduate Research, College's students 


\section{PENDAHULUAN}

Menjadi mahasiswa merupakan suatu langkah menuju gelar sarjana, yang diperoleh dengan menyelesaikan studi di sebuah perguruan tinggi dan membuat suatu karya ilmiah yang disebut skripsi (Lukman, 2007). Skripsi merupakan tugas akhir yang umumnya ditempuh pada semester ke-8, diluar ketentuan masa studi minimum 7 semester dan maksimum 12 semester (Peraturan Menteri Pendidikan Nasional Republik Indonesia, Nomor 73 Tahun 2009).

Masa studi 8 semester merupakan standar masa studi yang telah ditetapkan oleh pemerintah sebagai patokan masa studi ideal bagi perguruan tinggi di Indonesia, termasuk Universitas Syiah Kuala (Unsyiah) (Peraturan Pemerintah dan Kebudayaan Republik Indonesia Nomor 49, 2014). Hasil survei tracer study yang dilakukan oleh CDC Unsyiah (2016) diketahui bahwa terdapat banyak mahasiswa yang tidak dapat menyelesaikan studinya dalam masa yang ideal dikarenakan faktor keterlambatan penyelesaian skripsi. Dipenelitian lain Bakhtiar, \& Latif (2017) mengungkapkan bahwa jika studi cepat selesai akan berbanding dengan nilai IPK dan memdapatkan pekerjaan yang cepat.

Menurut Wurinanda (2015), masa penyusunan skripsi adalah masa yang sangat berpotensi menimbulkan kecemasan mahasiswa. Hal ini ditimbulkan oleh berbagai faktor seperti target lulus yang tidak tercapai dengan tepat waktu, banyaknya perbaikian skripsi, kesulitan dalam menemukan literatur, serta proses bimbingan yang sulit dan terkendala (Gunawati, Hartati, \& Listiara, 2006).

Lovibond dan Lovibond (1995) menyebutkan bahwa kecemasan adalah ketakutan atau kekhawatiran akan terjadinya hal yang tidak menyenangkan di masa mendatang. Kecemasan ditandai dengan perasaan akan terjadi masalah pada bagian otonomik, masalah pada otot, dan perasaan berada pada situasi yang salah atau tidak menyenangkan tanpa alasan yang jelas, serta dapat dipengaruhi pengalaman yang tidak menyenangkan di masa lalu mengenai kejadian serupa. Clark dan Watson (1991) menyebutkan bahwa kecemasan individu dilihat berdasarkan empat komponen yaitu autonomic arousal, skeletal musculature effects, situational anxiety, dan subjective experience of anxious affect.

Kecemasan dapat diatasi dengan metode relaksasi. Akan tetapi, metode ini tidak dapat dilakukan dengan efektif jika tidak disertai dengan kemampuan self awareness yaitu menyadari kondisi diri dan emosi (Berkovec, dalam Goleman, 2016). Kemampuan ini merupakan salah satu komponen dari kecerdasan emosional (Goleman, 2016).

Kecerdasan emosional adalah kemampuan dalam merasakan emosi, mengakses dan menghasilkan emosi yang dapat meringankan pikiran, dalam memahami emosi dan pengetahuannya, dalam mengatur emosi sesuai dengan kebutuhan dan perkembangan pengetahuan individu (Mayer \& Salovey, 1997). Kecerdasan emosional terdiri atas empat faktor yaitu perception of emotion, managing own emotions, managing other's emotion, dan utilization of emotion (Salovey \& Mayer, 1990).

Individu yang mempunyai kecerdasan emosional tinggi cenderung memiliki sikap yang tenang dalam menghadapi sesuatu, tidak cemas, tidak khawatir, tidak mudah takut, dan selalu berfikir matang sebelum bertindak melakukan sesuatu (Goleman, 2016). Akan tetapi, individu dengan tingkat kecerdasan emosional rendah cenderung mudah cemas karena tidak mampu mengontrol emosinya serta tidak mampu membaca situasi dengan baik.

Hal senada juga disebutkan oleh Utami (2009) dan Arsalan (2014) dalam penelitiannya. Hasil penelitian mereka menunjukkan bahwa terdapat hubungan negatif antara kecerdasan emosional dan kecemasan dalam menghadapi ujian. Hal ini menunjukkan bahwa tingginya kecerdasan emosional individu akan diikuti dengan rendahnya kecemasan. Sebaliknya, rendahnya kecerdasan emosional individu akan diikuti dengan tinginya kecemasan yang dialami.

Berdasarkan pemaparan di atas terlihat bahwa mahasiswa yang sedang menyusun skripsi berpotensi untuk mengalami kecemasan yang berkaitan erat dengan faktor emosi. Sebagaimana diketahui bahwa kecemasan merupakan hal yang wajar terjadi pada individu, namun jika tidak ditangani dengan benar dapat menjadi hal buruk hingga menghambat berbagai aspek kehidupan individu (Lovibond \& Lovibond, 1995). Hal ini tentunya akan 
memengaruhi kinerja mahasiswa dalam menyelesaikan skripsinya.

Salah satu cara untuk menangani kecemasan adalah dengan kemampuan mengelola emosi yang disebut kecerdasan emosi. Semakin tinggi kecerdasan emosi mahasiswa, akan diikuti dengan semakin baik pengelolaan emosinya, sehingga akan lebih mudah dalam menangani atau mengatasi kecemasan.

Kaitan antara kecerdasan emosional dengan kecemasan melakukan bimbingan skripsi pada mahasiswa merupakan hal menarik untuk diteliti secara lebih lanjut. Apakah kaitanya serupa dengan kecemasan dalam menghadapi ujian dan apakah kaitan antara dua variabel tersebut bersifat negatif ataupun positif. Oleh karena itu peneliti tertarik melakukan penelitian ini dengan tujuan untuk mengetahui "hubungan antara kecerdasan emosional dengan kecemasan dalam melakukan bimbingan skripsi pada mahasiswa Unsyiah".

\section{METODE PENELITIAN}

Penelitian ini merupakan penelitian kuantitatif dengan jenis korelasi. Populasi penelitian adalah seluruh mahasiswa tingkat akhir Unsyiah yang sedang mengerjakan skripsi. Pengambilan sampel dilakukan menggunakan teknik purposive sampling. Jumlah sampel pada penelitian ini adalah 257 Mahasiswa yang berasal dari 12 Fakultas di Unsyiah.

Data penelitian dikumpulkan menggunakan skala yang telah diterjemahkan ke dalam bahasa Indonesia. Proses penerjemahan dilakukan melalui dua tahap dengan bantuan dua orang penerjemah yang berbeda yaitu penerjemahan dari Bahasa Inggris ke Bahasa Indonesia, kemudian penerjemahan kembali dari Bahasa Indonesia ke Bahasa Inggris (backtranslation). Skala penelitian juga telah melalui expert review yang melibatkan tiga orang ahli dengan kualifikasi: dosen psikologi, dua diantaranya memiliki latar belakang pendidikan magister psikologi klinis, dan seorang yang berlatar belakang pendidikan magister psikologi riset.

Kecerdasan emosional diukur menggunakan Schutte Emotional Intelligence Scale (SEIS) yang disusun oleh Schutte, dkk (1998) berdasarkan konsep teoritis yang dikembangkan oleh Mayer dan Salovey pada tahun 1990. SEIS disusun berdasarkan 4 faktor yaitu perception of emotion, managing own emotions, managing other's emotions, dan utilization of emotion. SEIS terdiri dari 30 item favourabel dan 3 aitem unfavourabel dengan lima pilihan respon yaitu (1) sangat tidak setuju (STS), (2), tidak setuju (TS), (3) netral (N), (4) setuju (S), dan (5) sangat setuju (SS). Nilai 1-5 ini digunakan untuk pernyataan favorabel, sedangkan untuk pernyataan unfavorabel diberi nilai $5-1$.

SEIS diketahui memiliki validitas konstruk yang berkorelasi secara teoritikal dengan nilai reliabilitas alpha ( $\alpha$ ) 0,78 (Schutte, dkk, 1998). Hasil uji coba penelitian menunjukkan nilai alpha (a) 0,935 dan nilai alpha $(\alpha)$ 0,927 dalam penelitian.

Kecemasan diukur menggunakan skala kecemasan dari skala Depression Anxiety Stres Scale (DASS), yang telah diterjemahkan oleh Damanik (2006).DASS merupakan skala yang disusun oleh Lovibond dan Lovibond (1995) dan dalam pengembangannya telah teruji pada sampel normal dan non-klinis. DASS terdiri atas tiga skala yaitu depresi, kecemasan, dan stres. Skala kecemasan pada DASS disusun berdasarkan komponen autonomic arousal, skeletal musculature effects, situational anxiety, dan subjective experience of anxious affect. Skala kecemasan pada DASS terdiri atas 14 pernyataan favorable. Setiap pernyataan dinilai dengan skor antara 0 untuk setiap pernyataan yang tidak sesuai atau tidak pernah, skor 1 untuk setiap pernyataan yang sesuai sampai tingkat tertentu atau kadang-kadang, skor 2 untuk setiap pernyataan yang dapat dipertimbangkan atau lumayan sering, skor 3 untuk pernyataan sangat sesuai atau sering sekali.

DASS 42 yang telah diadaptasi ke dalam bahasa Indonesia oleh Damanik (2006) diketahui bahwa uji validitas dilakukan dengan menggunakan validitas konstruk dengan metode internal konsistensi. Sedangkan nilai reliabilitasnya dapat dilihat pada tabel berikut:

Tabel 1. Nilai reliabilitas DASS dan Skala kecemasan DASS

\begin{tabular}{lccc}
\hline \multicolumn{3}{c}{$\begin{array}{c}\text { Nilai Koefisien Reliabilitas } \\
\text { Cronbach's Alpha }(\boldsymbol{\alpha}) \\
\text { DASS }\end{array}$} & $\begin{array}{c}\text { Skala } \\
\text { Kecemasan } \\
\text { dalam DASS }\end{array}$ \\
\hline $\begin{array}{l}\text { Lovibond } \\
\text { Lovibond }\end{array}$ & dan & 0,91 & 0,81 \\
\cline { 1 - 1 } & & & \\
\end{tabular}




\begin{tabular}{lcc}
\hline$(1995)$ & & \\
Damanik & 0,948 & 0,851 \\
Uji coba & - & 0,910 \\
Penelitian & - & 0,921 \\
\hline
\end{tabular}

Data penelitian dianalisis menggunakan teknik one-sample kolmogrov smirnov untuk uji normalitas, anova test of linierity untuk uji linieritas, dan teknik analisis spearman untuk uji hipotesis. Analisis statistik ini menggunakan bantuan SPSS 24.0 for windows

\section{HASIL DAN PEMBAHASAN}

Deskripsi Data

Tabel 2. Deskripsi data penelitian

\begin{tabular}{|c|c|c|c|c|}
\hline \multicolumn{5}{|c|}{ Kecerdasan Emosional } \\
\hline & Xmaks & Xmin & Mean & SD \\
\hline $\begin{array}{l}\text { Data } \\
\text { Hipotetik }\end{array}$ & 165 & 33 & 99 & 22 \\
\hline Data Empirik & 159 & 59 & 118,2 & 18,13 \\
\hline \multicolumn{5}{|c|}{ Kecemasan } \\
\hline & Xmaks & Xmin & Mean & SD \\
\hline $\begin{array}{l}\text { Data } \\
\text { Hipotetik }\end{array}$ & 42 & 0 & 21 & 7 \\
\hline Data Empirik & 42 & 0 & 14,27 & 9,19 \\
\hline
\end{tabular}

Keterangan Rumus Skor Hipotetik :

1. Skor maksimal (Xmaks) adalah hasil perkalian jumlah butir skala dengan nilai tertinggi dari pembobotan pilihan jawaban

2. Skor minimal (Xmin) adalah hasil perkalian jumlah butir skala dengan nilai terendah dari pembobotan pilihan jawaban.

3. Mean $(\mu)$ dengan rumus $\mu=$ (skor maks + skor $\min ) / 2$

4. Standar deviasi $(\sigma)$ dengan rumus $\sigma=($ skor maks - skor min) $/ 6$

Deskripsi data kemudian digunakan sebagai perhitungan kategorisasi masing-masing variabel dalam penelitian ini. Berikut pengkategorisasian kecerdasan emosional:

Tabel 3. Kategorisasi Kecerdasan Emosional

\begin{tabular}{cc}
\hline $\begin{array}{c}\text { Rumusan Interval } \\
\text { Norma }\end{array}$ & $\begin{array}{c}\text { Norma } \\
\text { Kategori }\end{array}$ \\
\hline$X<(\mu-1,0 \sigma)$ & $X<77$ \\
$(\mu-1,0 \sigma) \leq X<(\mu+$ & $77 \leq X<121$ \\
$1,0 \sigma)$ & $121 \leq X$ \\
$(\mu+1,0 \sigma) \leq X$ &
\end{tabular}

Keterangan :

$\mu=$ Mean hipotetik pada skala $\sigma=$ Standar deviasi pada skala

\begin{tabular}{lccc}
\hline \multirow{2}{*}{ Kategori } & \multicolumn{2}{c}{ Mahasiswa } & \multirow{2}{*}{ Total } \\
\cline { 2 - 3 } & Jumlah & $\mathbf{\%}$ & \\
\hline $\begin{array}{l}\text { Less alexithymia } \\
\text { Greater clarity of } \\
\text { emotions }\end{array}$ & 13 & 5,2 & \\
$\begin{array}{l}\text { Greater attention to } \\
\text { emotions }\end{array}$ & 108 & 43,0 & $\mathbf{2 5 1}$ \\
\hline
\end{tabular}

Berikut pengkategorisasian kecemasan sebagaimana yang telah ditentukan oleh Lovibond dan Lovibond (1995):

Tabel 4. Norma dan Kategori Kecemasan

\begin{tabular}{llccl}
\hline Norma & \multirow{2}{*}{ Kategori } & \multicolumn{2}{c}{ Mahasiswa } & Total \\
\cline { 3 - 4 } Kategori & & Jumlah & $\mathbf{\%}$ & \\
\hline $0-7$ & Normal & 73 & 29,1 & \\
$8-9$ & Ringan & 22 & 8,8 & \\
$10-14$ & Sedang & 45 & 17,9 & \multirow{2}{*}{$\mathbf{2 5 1}$} \\
$15-19$ & Berat & 37 & 14,7 & \\
$20+$ & Sangat & 74 & 29,5 & \\
& Berat & & & \\
\hline
\end{tabular}

\section{Analisa Data Penelitian}

Uji asumsi mencakupi uji normalitas dan uji homogenitas/linieritas. Hasil uji normalitas pada 257 sampel menunjukkan nilai siginifikansi $p=0,003$ dengan nilai $\mathrm{KS}-\mathrm{Z}=1,814$ untuk variabel kecerdasan emosional dan $p=0,015$ untuk variabel kecemasan dengan nilai KS-Z $=1,567$. Nilai siginifikansi $p<0,05$ menunjukkan bahwa data dalam penelitian ini untuk kedua variabel tidak berdistribusi normal, dimana $p>0,05$.

Kemudian dilakukan uji outlier untuk melihat data subjek penelitian yang tidak baik dengan hasil terdapat 6 subjek penelitian yang outlier yaitu 20, 83, 109, 146, 163, dan 196.Data tersebut kemudian dibuang dan dianalisa dengan 251 sampel penelitian menunjukkan bahwa data pada kedua skala tidak berditribusi normal dengan nilai signifikansi untuk masingmasing skala adalah $p=0,005$ untuk skala kecemasan emosional dan $p=0,014$, dimana nilai signifikansi $p<0,05$. Analisa penelitian selanjutnya dilakukan menggunakan data penelitian dengan 251.

Selanjutnya, dilakukan uji linieritas pada 251 sampel dengan nilai signifikansi 
$p<0,05$ menunjukkan nilai signifikansi $p=0,000$, yang bermakna data penelitian linier.

Uji Hipotesis, berdasarkan uji asumsi pada 251 sampel diketahui bahwa data tidak berdistribusi normal, namun linier, maka uji hipotesa dilakukan menggunakan uji Spearman. Hasil uji menunjukkan nilai $p=0,022$ dan nilai $r_{\text {empiric }}=-0,145: r_{\text {tabel }}=0,104$. Hal ini menunjukkanbahwa hasil penelitian secara signifikan memiliki korelasi negatif yaitu semakin tinggi tingkat kecerdasan emosional individu, maka semakin rendah tingkat kecemasan individu tersebut. Begitu pula sebaliknya, semakin rendah tingkat kecerdasan emosional individu, maka akan semakin tinggi tingkat kecemasan individu tersebut.

Penelitian ini dilakukan untuk melihat hubungan antara kecerdasan emosional dengan kecemasan pada mahasiswa dalam melakukan bimbingan skripsi. Hasil analisa penelitian menunjukkan bahwa terdapat hubungan negatif antara kecerdasan emosional dengan kecemasan pada mahasiswa dalam melakukan bimbingan skripsi. Hubungan negatif ini menunjukkan bahwa semakin tinggi tingkat kecerdasan emosional mahasiswa, maka akan semakin rendah tingkat kecemasan yang dialaminya. Begitu pula sebaliknya, semakin rendah tingkat kecerdasan emosional mahasiswa tersebut, maka akan semakin tinggi tingkat kecemasan yang dialaminya.

Kecerdasan emosional merupakan salah satu faktor penting dalam kehidupan sebagaimana yang diungkapkan oleh Goleman (2016), bahwa kecerdasan emosional bertumpu pada hubungan antara perasaan, watak, dan naluri moral, yang membuat individu mampu mengendalikan dorongan emosi dirinya ataupun orang lain. Kecemasan merupakan salah satu bentuk manifestasi dari emosi takut yang ditandai dengan perasaan akan hadirnya sesuatu hal yang tidak menyenangkan. Individu dengan kecerdasan emosional tinggi akan mampu mengendalikan dan mengatasi emosi yang dirasakannya termasuk kecemasan.

Pada penelitian ini diketahui mayoritas mahasiswa berada pada tingkat kecemasan sangat beratdengan persentase $29,5 \%$ dan diikuti oleh tingkat kecemasan normal dengan persentase 29,1\%. Selanjutnya dilanjutkan dengan tingkat kecemasan sedang dengan presentase $<17 \%$ dan tingkat kecemasan berat $<15 \%$. Mahasiswa yang berada tingkat kecemasan ringan merupakan minoritas dalam penelitian dengan persentase <9\%. Hal ini membuktikan bahwa skripsi dapat menghadirkan kecemasan pada mahasiswa terutama mahasiswa Unsyiah. Hal ini dapat terjadi dikarenakan mahasiswa mengalami banyak kendala dalam melakukan bimbingan skripsi, seperti kesulitan mencari judul untuk skripsi, kesulitan mencari literatur dan bahan bacaan, atau takut menemui dosen pembimbing. Adanya berbagai kesulitan-kesulitan yang ditemui saat penyusunan skripsi oleh mahasiswa sering dirasakan sebagai suatu beban yang berat, akibatnya kesulitan-kesulitan yang dirasakan tersebut berkembang menjadi perasaan yang negatif yang akhirnya dapat menyebabkan mahasiswa menunda penyusunan skripsinya bahkan ada yang memutuskan untuk tidak menyelesaikan skripsinya (Mu'tadin, 2002).

Selanjutnya, ditinjau dari tingkat kecerdasan emosional mahasiswa diketahui bahwa mayoritas mahasiswa berada pada tingkat kecerdasan emosional tinggi dengan persentase $>51 \%$, diikuti dengan tingkat kecerdasan sedang yaitu $>42 \%$. Minoritas mahasiswa yaitu $>5 \%$ berada pada tingkat kecerdasan emosional rendah. Kecerdasan emosional diperlukan oleh individu ketika menghadapi suatu masalah yang dapat menimbulkan tekanan atau kecemasan bagi dirinya (Agung \& Budiani, 2013). Individu dengan tingkat kecerdasan emosional yang tinggi akan mampu mengatur emosinya sehingga dapat meminimalisasi atau bahkan menghindari perasaan cemas tersebut. Kecerdasan emosional juga berfungsi untuk menurunkan tingkat kecemasan itu sendiri. Selain itu, individu dengan tingkat kecerdasan emosional tinggi juga akan mampu mengelola emosi negatif yang dirasakannya menjadi sesuatu hal yang positif (Extremera, \& Fernández-Berrocal, 2006).

Tinggi rendahnya tingkatan kecerdasan emosional seseorang dipengaruhi oleh pengalaman, usia, jenis kelamin, jabatan (Goleman, 2016). Pada penelitian terlihat bahwa usia subjek berada pada tahap dewasa awal yaitu 21-26 tahun, dimana individu yang berada pada tahap dewasa awal sudah mampu berfikir secara kritis dan kompleks serta sudah mampu menalar masalah dengan baik. Goleman (2016) menambahkan bahwa semakin bertambahnya usia individu, maka akan semakin meningkat pula kecerdasan emosional individu tersebut. Ditinjau dari jenis kelamin, diketahui banyak subjek penelitian lebih didominasi oleh laki- 
laki.Walaupun dalam praktik kehidupan perempuan diketahui lebih unggul dari segi kecerdasan emosional dibandingkan laki-laki, namun terdapat pula laki-laki yang memiliki tingkat kecerdasan emosional yang lebih tinggi daripada perempuan (Goleman, 2016).

Berdasarkan analisa regresi diperoleh nilai $r=0,043$, yang menunjukkan bahwa kecerdasan emosional hanya berkontribusi sebesar 4,3\% terhadap tingkat kecemasan individu. Kecilnya kontribusi kecerdasan emosional dalam kecemasan individu dapat dipengaruhi oleh perbedaan fokus antara kecerdasan emosional dengan kecemasan.Herdiani (2012) menyebutkan bahwa kecerdasan emosional berfokus pada pengendalian emosi yang banyak berkaitan dengan aspek emosi, sedangkan kecemasan mahasiswa dalam menyusun skripsi lebih berfokus pada penyelesaian masalah atau problem solving dalam menyelesaikan penyusunan skripsi yang lebih banyak berkaitan dengan aspek kognitif (Herdiani, 2012). Selain itu, kecilnya kontribusi dalam penelitian ini juga dapat dipengaruhi oleh adanya outlier pada data penelitian yang mengganggu. Sebagaimana telah disebutkan sebelumnya bahwa terdapat beberapa data outlier pada penelitian ini, yang kemudian data tersebut dihilangkan. Akan tetapi, hasil perhitungan besaran kontribusi juga menunjukkan jumlah yang sedikit yaitu $<5 \%$.

Hasil penelitian Nuraini (2013) dan Dewi, Karini, dan Agustin (2012) menyebutkan bahwa terdapat hubungan antara kecerdasan emosi dengan kecemasan, namun pada Pegawai Negeri Sipil (PNS). Mahardika dan Rachmahama (2008) menyebutkan bahwa terdapat hubungan positif yang signifikan sebesar $6,8 \%$ antara kecerdasan emosi dengan kecemasan dalam menghadapai dunia kerja pada mahasiswa tingkat akhir.

Hasil yang berbeda ditemukan oleh Putri (2016), dimana tidak terdapat hubungan yang signifikan antara kecerdasan emosional dengan kecemasan pada mahasiswa dalam menyusun skripsi. Hasil penelitian Akbar (2013), Budiani (2013), dan Aswati (2014) juga menemukan bahwa tidak ada hubungan kecerdasan emosional dengan kecemasan pada mahasiswa yang sedang menyusun skripsi.

Lebih dari 95\% kecemasan pada mahasiswa dalam menyusun skripsi dipengaruhi oleh berbagai faktor lainnya berupa kemampuan individu dalam mengenali masalah, menyesuaikan diri dengan masalah, dan menyelesaikan masalah tersebut. Kemampuan ini disebut dengan problem solving (Rice, 1999). Kholisin (2014) menambahkan bahwa salah satu faktor yang memberikan kontribusi besar terhadap kecemasan adalah konsep diri. Stuart (2007) menambahkan bahwa kecemasan individu dapat dipengaruhi oleh kandungan benzodiazephine dalam jumlah banyak di dalam tubuh individu tersebut. Benzodiazephine adalah reseptor yang ada pada otak yang befungsi khusus untuk memicu kecemasan pada individu.

\section{SIMPULAN DAN SARAN}

Penelitian ini bertujuan untuk melihat hubungan kecerdasan emosional dengan kecemasan pada mahasiswa dalam melakukan bimbingan skripsi di Unsyiah. Hasil penelitian ini menunjukkan bahwa terdapat hubungan negatif antara kecerdasan emosional dengan kecemasan. Artinya semakin tinggi kecerdasan emosional mahasiswa, maka akan semakin rendah pula kecemasan mahasiswa tersebut. Begitu pula sebaliknya, semakin rendah kecerdasan emosional mahasiswa, maka akan semakin tinggi kecemasan mahasiswa tersebut.

Hasil kategorisasi penelitian menunjukkan bahwa mayoritas mahasiswa berada pada tingkat kecemasan sangat berat diikuti dengan mayoritas mahasiswa berada pada tingkat kecerdasan emosional tinggi. Perbedaan makna hipotesis dengan tingkat kategorisasi dapat dipangaruhi oleh nilai kontribusi kecerdasan emosional terhadap kecemasan yaitu sebesar $<5 \%$, sedangkan $>95 \%$ kecemasan dipengaruhi oleh hal lain seperti karakteristik individu, coping stres, hubungan dengan lingkungan sosial dan keluarga, dukungan sosial yang diterima, dan kemampuan kognitif.

Untuk para peneliti selanjutnya diharapkan agar dapat meneliti kecerdasan emosional ataupun kecemasan dengan menghubungkannya dengan variabel-variabel lain atau meneliti kedua variabel tersebut dari sudut pandang yang berbeda. Peneliti selanjutnya diharapkan dapat lebih mengembangkan penelitian ini dengan mencakupi berbagai bidang seperti industri dan organisasi, klinis, dan terapan lainnya. Selain itu, peneliti selanjutnya juga dapat mengembangkan penelitian ini dengan meneliti pada subjek yang berbeda seperti remaja atau mahasiswa S2. 


\section{DAFTAR RUJUKAN}

Agung, G., \& Budiani, M. S. (2013). Hubungan kecerdasan emosi dan self efficacy dengan tingkat stres mahasiswa yang sedang mengerjakan skripsi. Jurnal Online Universitas Surabaya, 1(02).

Akbar, A. (2013). Hubungan antara kecerdasan emosional dengan kecemasan pada mahasiswa Stikes Nani Hasanuddin Makassar yang sedang menyusun skripsi. Jurnal Ilmu Keperawatan, 2(1). ISSN: 2302-1721

Aswati, F H. (2014). Hubungan kecerdasan emosional dengan kemampuan menyelesaikan skripsi pada mahasiswa Program Studi Ilmu Keperawatan STIKES AISYIYAH Yogyakarta. Naskah Publikasi. Yogyakarta : Sekolah Tinggi Ilmu Kesehatan Aisyiyah. Diunduh di alamat website http://opac.say.ac.id/324/1/NASKAH \%20PUBLIKASI.pdf pada tanggal 16 Desember 2015.

Bakhtiar,M.I \& Latif,S. (2017) Tracer Study Alumni : Upaya Pengembangan Prodi Bimbingan Konseling Universitas Negeri Makassar. Jurnal Kajian Bimbingan dan Konseling, 2 (1)

Career Development Center [CDC]. (2016). Tracer Study Unsyiah. Diakses pada 8 April 2016, dari http://cdc.unsyiah.ac.id/tracerstudy/laporan.

Clark, L. A., \& Watson, D. (1991). Tripartite model of anxiety and depression: Psychometris evidence and taxonomic implicaions. Journal of Abromal Psychology, 100(3), 316-336

Damanik, E. D. (2011). The measurement of reliability, validity, items analysis and normative data of Depression Anxiety Stress Scale (DASS). Doctoral dissertation, Thesis. Fakultas Psikologi, Universitas Indonesia, Indonesia.

Dewi, A. K., Karini, S. M., \& Agustin, R. W. (2012). Hubungan antara kecerdasan emosi dengan kecemasan menghadapi masa pensiun pada pegawai negeri sipil. Jurnal Ilmiah Psikologi Candrajiwa, 1(1).
Extremera, N., \& Fernández-Berrocal, P. (2006).Emotional intelligence as predictor of mental, social, and physical health in university students. The Spanish Journal of Psychology, 9(01), 45-51.

Goleman, D. (2016). Kecerdasan Emosional. Jakarta: Penerbit Gramedia Pustaka Utama.

Gunawati, R., Hartati. S., \& Listiara, A. (2006). Hubungan antara efektivitas komunikasi mahasiswa-dosen pembimbing utama skripsi dengan stress dalam menyusun skripsi pada mahasiswa Program Studi Psikologi Fakultas Kedokteran Universitas Diponegoro. Jurnal psikologi Universitas Diponegoro, 3(2)

Herdiani, W. S. (2012). Pengaruh expressive writing pada kecemasan menyelesaikan skripsi. Calyptra; Jurnal ilmiah mahasiswa Universitas Surabaya, 1(1)

Kholisin. (2014). Kecemasan berbicara ditinjau dari konsep diri dan kecerdasan emosional. Jurnal Ilmu Dakwah, 34(1). ISSN: 1693-8054.

Lovibond, P. F., \& Lovibond, S. H. (1995). The structure of negative emotional state: comparison of Depression Anxiety Stress Scale (DASS) with The Beck Depression and Anxiety Inventories. Behavior Research Theory, 33(3)

Lukman, H. (2007). Sarjana Kebut Skripsi. Jakarta Selatan: Transmedia.

Mayer, J. D., \& Salovey, P. (1997).What Is Emotional Intelligence? In P. Salovey \& D. J. Sluyter (Eds.) Emotional Development and Emotional Intelligence. New York: Basic Books.

Mu'tadin, Z. (2002). Mengenal Kecerdasan emosional. Diakses dari http://www.epsikologi.com/

Nuraini, D. E. (2013). Kecerdasan emosional dan kecemasan menghadapi pensiun pada PNS. E-jurnal psikologi, 1(3), 324-331. ISSN: 0000-000

Peraturan Menteri Pendidikan Dan Kebudayaan Republik Indonesia Nomor 49 Tahun 2014 tentang Standar Nasional Pendidikan Tinggi.

Peraturan Menteri Pendidikan Nasional Republik Indonesia Nomor 73 Tahun 
2009 tentang Perangkat akreditasi program studi sarjana (S1).

Rice, P.L. (1999). Stress and Health. Third edition. Moorhead State University: Brooks/Cole Publishing Company.

Salovey, P., Brackett, M. A., \& Mayer, J. D. (2004). Emotional intelligence: Key readings on the Mayer and Salovey model. Naples:National professional resources inc/Dude publishing. ISBN: 1887943722,9781887943727

Salovey, P., \& Mayer, J. D. (1990).Emotional intelligence. Baywood Publishing Co., Inc.

Schutte, N.S., Malouff, J.M., Hall, L.E., Haggerty, D.J., Cooper, J.T., Golden, C., \& Dornheim, L. (1998). Development and validation of a measure of emotional intelligence. Personality and Individual Differences, 25(2), 167-177.

Stuart, G. W. (2007). Buku Saku Keperawatan Jiwa. Jakarta: EGC.

Universitas Syiah Kuala. (2016). Data Mahasiswa Aktif. Diakses pada 1 Januari 2016, dari http://www.data.Universitas Syiah Kuala.ac.id/

Wurinanda, I. (2015, September 1). Masalah yang Umum Dihadapi Mahasiswa. Okezonekampus. Diakses dari http://news.okezone.com/read/2015/08 /31/65/1205758/masalah-yang-umumdihadapi-mahasiswa 